\title{
Distribution and diversity of echinoderms (Asteroidea, Echinoidea, Holothuroidea) in the islands of the Gulf of Chiriqui, Panama
}

\author{
Distribución y diversidad de equinodermos (Asteroidea, Echinoidea, Holothuroidea) \\ en las islas del Golfo de Chiriquí, Panamá
}

\begin{abstract}
Juan José Alvarado ${ }^{1,2}$, Héctor M. Guzman ${ }^{3}$ and Odalisca Breedy ${ }^{1,3,4}$
${ }^{1}$ Centro de Investigación en Ciencias del Mar y Limnología (CIMAR), Universidad de Costa Rica, San Pedro, 11501-2060 San José, Costa Rica.juan.alvarado@ucr.ac.cr, juanalva76@yahoo.com

${ }^{2}$ Posgrado en Ciencias Marinas y Costeras, Universidad Autónoma de Baja California Sur, La Paz, México

${ }^{3}$ Smithsonian Tropical Research Institute, PO Box 0843-03092, Balboa, Ancón, Panamá

${ }^{4}$ Museo de Zoología, Escuela de Biología, Universidad de Costa Rica, San Pedro de Montes de Oca, Apartado Postal 2060, San José, Costa Rica
\end{abstract}

Resumen.-Los estudios de equinodermos en el Pacífico Panameño han sido enfocados principalmente en análisis moleculares y evolutivos, y los pocos trabajos ecológicos se han enfatizado en dos especies: Diadema mexicanum y Acanthaster planci. En este trabajo, se describe por primera vez la diversidad (basado en los índices de Margalef, Shannon y Pielou), distribución y densidad de equinodermos de algunas islas del Golfo de Chiriquí, utilizando una metodología regional estandarizada para el Corredor Marino de Conservación del Pacífico Tropical Oriental. Se estudiaron 53 sitios, encontrándose 17 especies de equinodermos: 6 asteroideos, 6 equinoideos y 5 holoturoideos. Los valores promedio de los índices de riqueza de especies, diversidad de Shannon y equidad de Pielou fueron $0,43 \pm 0,04,0,187 \pm 0,020$, y $0,421 \pm 0,035$ respectivamente. En promedio se encontró 3 especies y 176 individuos por sitio. Tres especies de equinoideos fueron las más abundantes: D. mexicanum, Eucidaris thoaursii and Echinometra vanbrunti, con 7909, 771 y 569 individuos respectivamente. A pesar de dichas abundancias, su impacto, al igual que otros organismos coralívoros (e.g., A. planci), es bajo y por el momento no son consideradas como amenazas para los arrecifes de la zona. Los sitios con mayor riqueza y diversidad de especies están asociados a sitios de mayor diversidad de corales y con una cobertura de coral vivo de moderada a alta. Se sugiere la evaluación continua de las poblaciones que podrían ser perjudiciales, así como de las especies que pueden estar bajo extracción ilegal.

Palabras clave: Diadema mexicanum, Acanthaster planci, arrecife coralino, Pacífico Tropical Oriental, paisaje marino

Abstract. - Studies on echinoderms along the Panamanian Pacific coast have focused mainly on evolutionary and molecular analyses, however little ecological research has been done and mainly only on 2 species: Diadema mexicanum and Acanthaster planci. Herein, we describe for the first time the diversity (based on Margalef, Shannon and Pielou indices), distribution and density of echinoderms for some islands of the Gulf of Chiriqui, implementing a standard regional methodology used for the Eastern Tropical Pacific Conservation Seascape. Fiftythree reef sites were surveyed, of which 17 echinoderm species were found: 6 asteroids, 6 echinoids and 5 holothuroids. The average species richness, Shannon diversity, and Pielou's evenness indices were $0.43 \pm 0.04$, $0.187 \pm 0.020$, and $0.421 \pm 0.035$ respectively. On average there were 3 species and 176 individuals per site. Three echinoid species were the most abundant: D. mexicanum, Eucidaris thoaursii and Echinometra vanbrunti, with 7909, 771 and 569 individuals respectively. Despite the high abundance observed, their impact on the reefs as well as other corallivores species (e.g., A. planci) is low, and for the moment they are not considered a threat to the reefs. Reef zones with greater richness and diversity of echinoderm species are associated with sites showing higher coral diversity and moderate to high live coral cover. We suggest a continuous assessment of the populations possibly damaging these ecosystems, as well those species that may be under illegal extraction.

Key words: Diadema mexicanum, Acanthaster planci, coral reef, Eastern Tropical Pacific, seascape 


\section{INTRODUCTION}

Understanding the composition, diversity and distribution of echinoderms in coral reef environments is necessary, not only because of their value in terms of diversity that they may contribute within a particular site, but also for their relevance in the functioning of coral reef environments. Echinoderms are a source of food and at the same time are primary consumers (e.g., algae, sediments, and suspended detritus), and highly efficient carnivores or scavengers. They are important components of coral reefs, and understanding their ecology allows for the characterization of the structure and function of coral communities (Birkeland 1989, Hughes 1994, Bellwood et al. 2004). It has been documented that in coral reefs, echinoderms achieve high diversity and biomass (Birkeland 1989).

The Pacific coast of Panama is an area considered as having one of the greatest diversity of coral reefs in the Eastern Tropical Pacific (ETP) (Glynn \& Ault 2000, Guzman \& Breedy 2008), with 23 species of scleractinian corals and 3 species of milleporid corals (Maté 2003). Moreover, the best reef development occurs in the Gulf of Chiriqui, where 22 species of corals can be found, and 6 of them are found exclusively within this region of the country. Panama also has one of the largest coral reefs of the Pacific coast of America, with 1703 ha within the Coiba National Park (Maté 2003, Guzman et al. 2004). In addition, the Pacific coast of Panama has two Gulfs with different oceanographic conditions. The Gulf of Panama is a zone where seasonal upwelling occurs from December to April, whereas the Gulf of Chiriqui is a zone oceanographically more stable than the former (D'Croz \& Robertson 1997, Cortés 2007, D'Croz \& Odea 2007). Apart from its biological and oceanographic richness, both gulfs have more than 705 islands and islets: 250 in the Gulf of Panama and 455 in Chiriqui's (Guzman \& Breedy 2008, Guzman et al. 2008), providing a variety of habitats with a high diversity and development of marine organisms.

These conditions have made the Pacific coast of Panama the most echinoderm-diverse of all the ETP, with 253 species (Maluf 1988, Alvarado et al. 2010). However, despite this great richness, the ecological studies that have been made are few or have been directed to particular species, mainly the crown-of-thorns seastar Acanthaster planci, and the black sea urchin Diadema mexicanum. Regarding the former, their distribution, density and feeding patterns (Glynn 1973, 1974, 1982), the relationship with their predators (Glynn 1977, 1981, 1984), and the impact of the El Niño phenomenon on their prey and their population (Glynn 1985a, b, 1990, Fong \& Glynn 1988) have been studied in the Gulf of Chiriqui. Similarly, studies related to D. mexicanum have been focused on its impact as bioeroder before and after El Niño events (Glynn 1988, Eakin 1992, 1996, 2001) and its relationship to damselfishes (Eakin 1987). Studies focusing on other species or groups are scarce, highlighting only two studies, one that described the behavior of the irregular sea urchin populations Mellitella stokesii (see Dexter 1977), and another that described the association between juveniles and adults of the brittlestar Ophiocoma aethiops (see Hendler et al. 1999). Most recent research on echinoderms in the Pacific coast of Panama has focused exclusively on molecular and evolutionary studies (e.g., Lessios 1979, 1981, 1990, 2010, Lessios et al. 2001).

Consequently, there is no study describing the diversity and abundance of echinoderm species on the Pacific coast of Panama. The present article aimed to describe for the first time the abundance, distribution and diversity (Margalef, Shannon and Pielou indices) of shallow-water echinoderms $(0-17 \mathrm{~m})$ in 53 sites around the major islands of the Gulf of Chiriqui. Likewise, as the Gulf of Chiriqui is composed of a variety of MPAs that possess a high richness and coral cover, we wanted to determine if there is some association between the level of coral cover and richness with the composition and richness of shallow water echinoderms.

\section{Materials AND METHODS}

The Gulf of Chiriqui is located southwest of the Republic of Panama, from Punta Burica, Chiriqui Province up to Punta Ventanas in the Province of Veraguas (EGUP 2001). There are 8 protected areas under different management categories in the Gulf of Chiriqui, of which the Coiba National Park (CNP) covers the largest area (Guzman et al. 2004). The CNP is a UNESCO World Heritage Site and is part of the Marine Conservation Seascape of the Eastern Tropical Pacific, which includes the Galapagos archipelago and the Malpelo, Gorgona and Cocos Islands (Guzman \& Breedy 2008). The gulf includes approximately 455 islands and islets, in 4 archipelagos (Paridas, Secas, Contreras and Coiba) with an insular area of $775 \mathrm{~km}^{2}$ (Guzman \& Breedy 2008).

Fifty-three sites were evaluated between the 18th and 30th of March 2007 (Fig. 1, Table 1). Those sites where chosen as representatives of different habitats around the islands and islets. Two depths were studied at each site (0-8 and 9-17 m), depending on the bottom characteristics and the dive sites. In each depth range, 5 


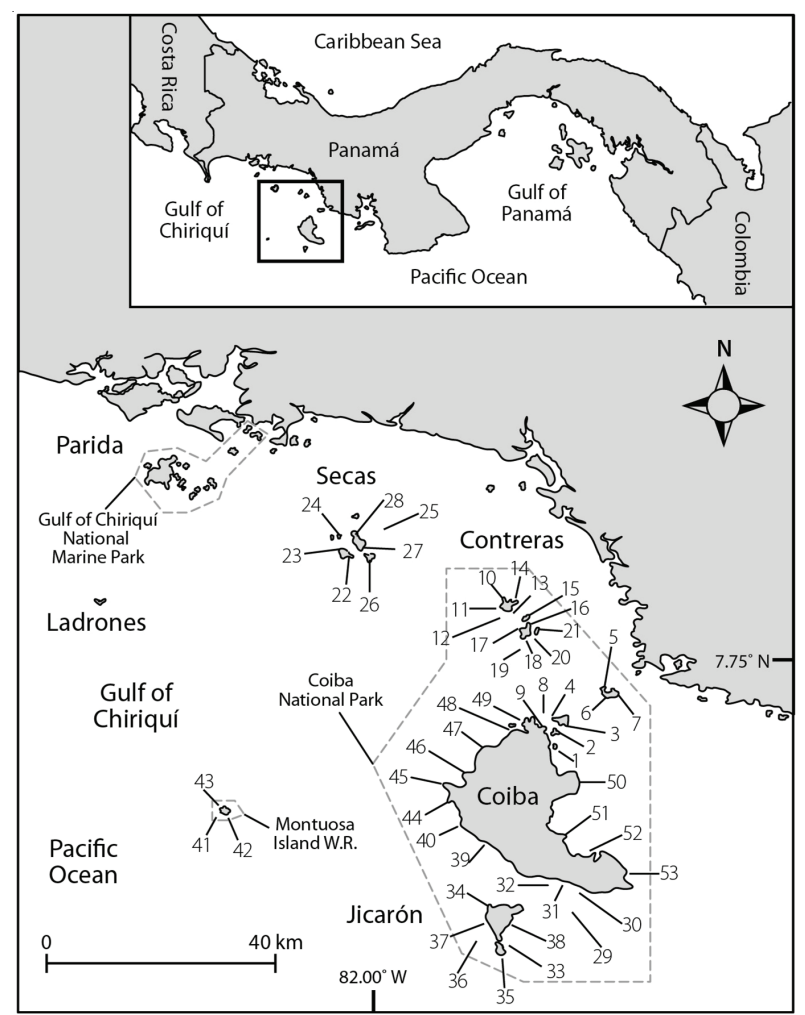

Figure 1. Location of sampling sites in the islands of the Gulf of Chiriqui, Panama. Sites numeration in Table 1 / Ubicación de los sitios de muestreo en las islas del Golfo de Chiriquí, Panamá. Numeración de los sitios en la Tabla 1 transects of $10 \mathrm{~m}$ long were made. Each transect was assessed to $1 \mathrm{~m}$ on each side using a PVC pipe as a reference, quantifying in detail all echinoderms present in any cavity or hollow and without moving any rock or coral (Edgar et al. 2004, Alvarado \& Chiriboga 2008).

The Margalef species richness (d), Shannon's diversity $\left(H^{\prime}\right)$, Pielou's evenness $(J)$ indices and the density of individuals $\left(\mathrm{m}^{-2}\right)$ per species were calculated for each site. Likewise, the composition similarity between sites was compared, after standardizing and transforming $(\log (\mathrm{x}+1)$ the data, using a Bray-Curtis similarity matrix, through a group average cluster, a multidimensional scaling analysis (MDS), and using the live coral cover as factors (Guzman et al. 2004, Guzman \& Breedy 2008). An analysis of similarity (ANOSIM) among the study sites was performed to identify if there are no assemblage differences between sites according to the factor of live coral cover. As well, using the same factor, an analysis of similarity percentages (SIMPER) was performed to assess the degree of contribution of each species, using BrayCurtis as a measure of similarity. These tests were carried out using the software PRIMER 6.0 (Clarke \& Gorley 2005). Moreover, in order to determine if there are any differences between the coral cover level and the diversity indices, a series of analysis of variance (ANOVA) were carried out. In the case that the data did not fulfill

Table 1. List of the sampling sites in the Gulf of Chiriqui islands, Panama / Lista de los sitios de muestreo en las islas del Golfo de Chiriquí, Panamá

\begin{tabular}{|c|c|c|c|c|c|c|c|}
\hline Site \# & Name & North & West & Site \# & Name & North & West \\
\hline 1 & Granito Oro & $07^{\circ} 35.584^{\prime}$ & $081^{\circ} 42.603^{\prime}$ & 28 & Islote Cavada NE & $08^{\circ} 00.017^{\prime}$ & $082^{\circ} 01.566^{\prime}$ \\
\hline 2 & Islote Coco Norte & $07^{\circ} 37.417^{\prime}$ & $081^{\circ} 42.700^{\prime}$ & 29 & Hill Rocks & $07^{\circ} 17.112^{\prime}$ & $081^{\circ} 40.381^{\prime}$ \\
\hline 3 & Iglesia & $07^{\circ} 37.977^{\prime}$ & $081^{\circ} 41.656^{\prime}$ & 30 & Barco Quebrado & $07^{\circ} 19.083^{\prime}$ & $081^{\circ} 40.367^{\prime}$ \\
\hline 4 & Islote Frijol N & $07^{\circ} 39.010^{\prime}$ & $081^{\circ} 43.107^{\prime}$ & 31 & Pasage Rock & $07^{\circ} 18.983^{\prime}$ & $081^{\circ} 42.667^{\prime}$ \\
\hline 5 & Afuerita $\mathrm{N}$ & $07^{\circ} 42.384^{\prime}$ & $081^{\circ} 38.109^{\prime}$ & 32 & Logan Rock & $07^{\circ} 19.844^{\prime}$ & $081^{\circ} 43.451^{\prime}$ \\
\hline 6 & Canal Afuera SO & $07^{\circ} 41.513^{\prime}$ & $081^{\circ} 38.372^{\prime}$ & 33 & Jicarita Este & $07^{\circ} 12.783^{\prime}$ & $081^{\circ} 47.917^{\prime}$ \\
\hline 7 & Canal Afuera SE & $07^{\circ} 41.228^{\prime}$ & $081^{\circ} 36.698^{\prime}$ & 34 & Jicaron Noroeste & $07^{\circ} 17.876^{\prime}$ & $081^{\circ} 49.409^{\prime}$ \\
\hline 8 & Roca Coibita & $07^{\circ} 39.372^{\prime}$ & $081^{\circ} 43.809^{\prime}$ & 35 & Jicarita Sur & $07^{\circ} 12.193^{\prime}$ & $81^{\circ} 47.921^{\prime}$ \\
\hline 9 & Coiba NE & $07^{\circ} 37.963^{\prime}$ & $081^{\circ} 44.062^{\prime}$ & 36 & La Catedral & $07^{\circ} 13.601^{\prime}$ & $081^{\circ} 49.757^{\prime}$ \\
\hline 10 & Brincanco N & $07^{\circ} 52.470^{\prime}$ & $081^{\circ} 47.683^{\prime}$ & 37 & Jicaron Oeste & $07^{\circ} 15.459^{\prime}$ & $081^{\circ} 49.435^{\prime}$ \\
\hline 11 & Brincanco SO & $07^{\circ} 51.207^{\prime}$ & $081^{\circ} 48.150^{\prime}$ & 38 & Jicaron Este & $07^{\circ} 15.967^{\prime}$ & $081^{\circ} 46.983^{\prime}$ \\
\hline 12 & Bajo Urraca & $07^{\circ} 50.346^{\prime}$ & $081^{\circ} 47.794^{\prime}$ & 39 & Punta Piedra Hueca & $07^{\circ} 24.324^{\prime}$ & $081^{\circ} 49.094^{\prime}$ \\
\hline 13 & Brincanco SE & $07^{\circ} 50.986^{\prime}$ & $081^{\circ} 47.249^{\prime}$ & 40 & Piedra Hacha & $07^{\circ} 25.951^{\prime}$ & $081^{\circ} 51.474^{\prime}$ \\
\hline 14 & Pajaros NE & $07^{\circ} 52.224^{\prime}$ & $081^{\circ} 46.617^{\prime}$ & 41 & Bajo Montuosa Oeste & $07^{\circ} 28.281^{\prime}$ & $082^{\circ} 15.954^{\prime}$ \\
\hline 15 & Sin Nombre NE & $07^{\circ} 50.576^{\prime}$ & $081^{\circ} 45.234^{\prime}$ & 42 & Montuosa Sureste & $07^{\circ} 27.745^{\prime}$ & $082^{\circ} 13.924^{\prime}$ \\
\hline 16 & Uva NE & $07^{\circ} 49.601^{\prime}$ & $081^{\circ} 45.495^{\prime}$ & 43 & Montuosa Norte & $07^{\circ} 28.670^{\prime}$ & $082^{\circ} 14.598^{\prime}$ \\
\hline 17 & Almohada N & $07^{\circ} 49.162^{\prime}$ & $081^{\circ} 46.292^{\prime}$ & 44 & Punta Adelarda & $07^{\circ} 29.254^{\prime}$ & $081^{\circ} 53.318^{\prime}$ \\
\hline 18 & Uva S & $07^{\circ} 48.062^{\prime}$ & $081^{\circ} 45.663^{\prime}$ & 45 & Bajo Telesto & $07^{\circ} 31.083^{\prime}$ & $081^{\circ} 53.735^{\prime}$ \\
\hline 19 & Prosper & $07^{\circ} 46.572^{\prime}$ & $081^{\circ} 45.601^{\prime}$ & 46 & Punta Hermosa Norte & $07^{\circ} 32.661^{\prime}$ & $081^{\circ} 51.539^{\prime}$ \\
\hline 20 & Uvita Abajo & $07^{\circ} 48.145^{\prime}$ & $081^{\circ} 44.762^{\prime}$ & 47 & Bajo Twin Peaks & $07^{\circ} 35.133^{\prime}$ & $081^{\circ} 50.500^{\prime}$ \\
\hline 21 & Uvita Arriba & $07^{\circ} 49.157^{\prime}$ & $081^{\circ} 44.327^{\prime}$ & 48 & Islote Santa Cruz & $07^{\circ} 37.868^{\prime}$ & $081^{\circ} 46.932^{\prime}$ \\
\hline 22 & Secas SE & $07^{\circ} 57.126^{\prime}$ & $082^{\circ} 02.197^{\prime}$ & 49 & Punta Baltazar Oeste & $07^{\circ} 38.776^{\prime}$ & $081^{\circ} 45.669^{\prime}$ \\
\hline 23 & Islote Secas N & $07^{\circ} 57.850^{\prime}$ & $082^{\circ} 03.465^{\prime}$ & 50 & Punta Damas & $07^{\circ} 31.003^{\prime}$ & $081^{\circ} 40.250^{\prime}$ \\
\hline 24 & Larry & $07^{\circ} 59.492^{\prime}$ & $082^{\circ} 04.345^{\prime}$ & 51 & Punta Felipa & $07^{\circ} 25.309^{\prime}$ & $081^{\circ} 41.729^{\prime}$ \\
\hline 25 & Roca Bruja & $07^{\circ} 59.467^{\prime}$ & $081^{\circ} 58.950^{\prime}$ & 52 & Bahia Damas Sur & $07^{\circ} 23.877^{\prime}$ & $081^{\circ} 39.558^{\prime}$ \\
\hline 26 & Secas E & $07^{\circ} 56.853^{\prime}$ & $082^{\circ} 01.339^{\prime}$ & 53 & Punta Anegada & $07^{\circ} 20.828^{\prime}$ & $081^{\circ} 35.456^{\prime}$ \\
\hline 27 & Secas O & $07^{\circ} 58.504^{\prime}$ & $082^{\circ} 01.104^{\prime}$ & & & & \\
\hline
\end{tabular}


the analysis assumptions, we performed a Kruskal-Wallis test. These analyses were carried out using the software SygmaStat 3.5.

Because the sea urchin Diadema mexicanum was the only one that appeared in all sites and depths, an analysis of variance was done to determine differences between densities by depth, taking each depth zone at each site. Depth zones were classified into three categories: 1) shallow: 1-4 m, 2) intermediate: 5-9 m, and 3) deep: 10-17 $\mathrm{m}$. A Tukey multiple comparison a posteriori test was applied to determine which depth explains the differences. The data were $\log (\mathrm{x}+1)$ transformed. This analysis was done using the software SYSTAT 8.0 (SYSTAT 1998).

\section{RESULTS}

Seventeen species of echinoderms were observed throughout all the sites sampled (Table 2), 6 Asteroids, 6 Echinoids and 5 Holothuroids. Among the asteroids,
Pentaceraster cumingi and Phataria unifascilis were the most abundant, with 11 and 10 individuals respectively. The echinoids were the most notable, with a total of 9274 individuals, where D. mexicanum was the most abundant with 7909 individuals, followed by Eucidaris thouarsii and Echinometra vanbrunti with 771 and 569 individuals, respectively (Table 2). The Holothuroids were the least abundant with only 17 individuals (Table 2). Also we report that in the study area, the seacucumber Euapta godeffroyi and the seastar Nidorellia armata were found outside the sites sampled. The sea cucumbers Holothuria fuscocinerea and Stichopus horrens have not previously been recorded for the Pacific coast.

Most echinoderms showed low densities between 0.01 and 0.02 individuals $\mathrm{m}^{-2}$ (Table 2). The highest densities corresponded to the echinoids $D$. mexicanum, $E$. thouarsii and $E$. vanbrunti with $0.77,0.25$ and 0.11 individuals $\mathrm{m}^{-2}$, respectively (Table 2 ). In the case of $D$.

Table 2. Total number of individuals observed, average density (ind. $\mathrm{m}^{-2} \pm$ standard error) and number of sites where echinoderms were observed during the assessments of the islands of the Gulf of Chiriqui / Número total de individuos observados, densidad promedio (ind. $\mathrm{m}^{-2} \pm$ error estándar) y número de sitios donde los equinodermos fueron observados durante la evaluación en las islas del Golfo de Chiriquí

\begin{tabular}{|c|c|c|c|c|c|}
\hline Specie & $\mathrm{N}^{\circ}$ ind. & Ind. $\mathrm{m}^{-2}$ & Mín. & Máx. & $\mathrm{N}^{\circ}$ sites \\
\hline \multicolumn{6}{|l|}{ Asteroidea } \\
\hline Pentaceraster cumingi (Gray, 1840) & 11 & $0.02 \pm 0.00$ & 0.01 & 0.03 & 4 \\
\hline Linckia guildingi Gray 1840 & 1 & 0.01 & - & - & 1 \\
\hline Pharia pyramidatus (Gray, 1840) & 6 & $0.02 \pm 0.00$ & 0.01 & 0.02 & 4 \\
\hline Phataria unifascialis (Gray, 1840) & 10 & $0.02 \pm 0.01$ & 0.01 & 0.04 & 3 \\
\hline Mithrodia bradleyi Verrill, 1867 & 1 & 0.01 & - & - & 1 \\
\hline Acanthaster planci (Linnaeus, 1758) & 3 & $0.01 \pm 0.00$ & - & - & 3 \\
\hline \multicolumn{6}{|l|}{ Echinoidea } \\
\hline Eucidaris thouarsii (Valenciennes, 1846) & 771 & $0.11 \pm 0.02$ & 0.01 & 0.60 & 45 \\
\hline Astropyga pulvinata (Lamarck, 1816) & 1 & 0.01 & - & - & 1 \\
\hline Diadema mexicanum A. Agassiz, 1863 & 7909 & $0.77 \pm 0.12$ & 0.01 & 9.05 & 53 \\
\hline Toxopneustes roseus (A. Agassiz, 1863) & 9 & $0.01 \pm 0.00$ & 0.01 & 0.03 & 6 \\
\hline Tripneustes depressus A. Agassiz, 1863 & 15 & $0.04 \pm 0.02$ & 0.01 & 0.08 & 3 \\
\hline Echinometra vanbrunti A. Agassiz, 1863 & 569 & $0.25 \pm 0.07$ & 0.01 & 1.23 & 21 \\
\hline \multicolumn{6}{|l|}{ Holothuroidea } \\
\hline Cucumaria flamma Solís \& Laguarda, 1999 & 2 & $0.01 \pm 0.00$ & - & - & 2 \\
\hline Holothuria (Halodeima) hilla Lesson, 1830 & 2 & $0.01 \pm 0.00$ & - & - & 2 \\
\hline Holothuria (Mertensiothuria) fuscocinerea Jaeger, 1833 & 3 & $0.01 \pm 0.00$ & - & - & 2 \\
\hline Isostichopus fuscus (Ludwig, 1875) & 8 & $0.01 \pm 0.00$ & 0.01 & 0.02 & 5 \\
\hline Stichopus horrens Selenka, 1867 & 2 & $0.01 \pm 0.00$ & - & - & 2 \\
\hline
\end{tabular}


mexicanum, the highest density ( 9.05 individuals $\mathrm{m}^{-2}$ ) was observed in site 9 at $2 \mathrm{~m}$ depth. Significant differences between the amount of $D$. mexicanum and depth were observed $\left(\mathrm{F}_{2,101}=7,603, P<0.05\right)$, where a difference was shown at $1-4 \mathrm{~m}$ depth (Tukey, $P<0.05$ ). When $D$. mexicanum was observed $(\sim 80 \%)$, the presence of the arrow crab (Stenorhynchus debilis) was recorded between the urchin's spines, sometimes finding up to 3 crabs per sea urchin.

On average there were $2.96 \pm 0.16$ species per site, with a minimum of one and a maximum of five. Sites with fewer species per site were $1,10,11,12,27$, which also had the lowest values of Margalef species richness and Shannon diversity indices (Table 3 ). Most sites (32\%) had 2 species, $25 \%$ had 4 species, $23 \%$ had 3 species, $11 \%$ had 6 species and $9 \%$ had only 1 species. The average number of individuals of all species observed per site was $176 \pm 27$ ind. site $^{-1}$, with a minimum of 4 ind. for site 6 and a maximum of 1045 ind. for site 9 . The average species richness per site (d) was $0.43 \pm 0.04$, being highest at site 39 (1.15; Table 3). The average Shannon diversity $(\mathrm{H})$ index was $0.187 \pm 0.020$, with a maximum value of 0.447 for site 39 . The average value of Pielou's evenness index was 0.421 \pm 0.035 , being lowest at sites $9,28,52$ and 51 , while the highest occurred at site 19 (Table 3).

Table 3. Total species (S), total individuals (N), Margalef species richness (d), Shannon diversity ( $\left.\mathrm{H}^{\prime}\right)$ and Pielou's evenness ( $\mathrm{J}$ ') of shallow-water echinoderms of the Gulf of Chiriqui islands. Coral cover level (CC): high = 1; intermediate = 2; low = 3 (based on Guzman et al. 2004, Guzman \& Breedy 2008) / Especies totales $(\mathrm{S})$, individuos totales $(\mathrm{N})$, riqueza de especies de Margalef (d), diversidad de Shannon ( $\mathrm{H}^{\prime}$ ) y equidad de Pielou ( $\mathrm{J}^{\prime}$ ) de los equinodermos de aguas someras en las islas del Golfo de Chiriquí. Nivel de cobertura de coral (CC): alto =1; intermedio = 2; bajo = 3 (basado en Guzman et al. 2004, Guzman \& Breedy 2008)

\begin{tabular}{|c|c|c|c|c|c|c|c|c|c|c|c|c|c|}
\hline Site & $\mathrm{S}$ & $\mathrm{N}$ & $\mathrm{d}$ & $\mathrm{J}^{\prime}$ & $\mathrm{H}^{\prime}$ & $\mathrm{CC}$ & Site & $\mathrm{S}$ & $\mathrm{N}$ & $\mathrm{d}$ & $\mathrm{J}^{\prime}$ & $\mathrm{H}^{\prime}$ & $\mathrm{CC}$ \\
\hline 1 & 1 & 8 & 0 & - & 0 & 1 & 28 & 2 & 515 & 0.16 & 0.002 & 0.001 & 2 \\
\hline 2 & 4 & 88 & 0.67 & 0.550 & 0.331 & 1 & 29 & 2 & 26 & 0.30 & 0.235 & 0.007 & 3 \\
\hline 3 & 3 & 80 & 0.46 & 0.721 & 0.344 & 1 & 30 & 4 & 131 & 0.61 & 0.711 & 0.428 & 3 \\
\hline 4 & 3 & 115 & 0.42 & 0.497 & 0.237 & 2 & 31 & 4 & 154 & 0.59 & 0.502 & 0.302 & 3 \\
\hline 5 & 2 & 78 & 0.23 & 0.172 & 0.005 & 2 & 32 & 3 & 101 & 0.43 & 0.706 & 0.337 & 3 \\
\hline 6 & 2 & 4 & 0.72 & 0.811 & 0.244 & 2 & 33 & 5 & 120 & 0.83 & 0.380 & 0.265 & 1 \\
\hline 7 & 5 & 105 & 0.86 & 0.455 & 0.318 & 1 & 34 & 2 & 47 & 0.25 & 0.819 & 0.246 & 1 \\
\hline 8 & 3 & 114 & 0.42 & 0.009 & 0.004 & 2 & 35 & 3 & 284 & 0.35 & 0.830 & 0.396 & 1 \\
\hline 9 & 2 & 1045 & 0.14 & 0.002 & 0.001 & 1 & 36 & 2 & 386 & 0.16 & 0.304 & 0.009 & 3 \\
\hline 10 & 1 & 134 & 0 & - & 0 & 1 & 37 & 4 & 221 & 0.55 & 0.350 & 0.210 & 3 \\
\hline 11 & 1 & 18 & 0 & - & 0 & 1 & 38 & 3 & 28 & 0.60 & 0.508 & 0.242 & 2 \\
\hline 12 & 1 & 135 & 0 & - & 0 & 1 & 39 & 5 & 32 & 1.15 & 0.640 & 0.447 & 2 \\
\hline 13 & 4 & 256 & 0.54 & 0.372 & 0.224 & 1 & 40 & 2 & 360 & 0.16 & 0.699 & 0.210 & 2 \\
\hline 14 & 4 & 227 & 0.55 & 0.166 & 0.100 & 1 & 41 & 3 & 625 & 0.31 & 0.626 & 0.298 & 1 \\
\hline 15 & 3 & 214 & 0.37 & 0.279 & 0.133 & 1 & 42 & 4 & 241 & 0.54 & 0.658 & 0.396 & 1 \\
\hline 16 & 4 & 183 & 0.57 & 0.255 & 0.153 & 1 & 43 & 3 & 148 & 0.40 & 0.155 & 0.007 & 1 \\
\hline 17 & 2 & 49 & 0.26 & 0.144 & 0.004 & 2 & 44 & 5 & 382 & 0.67 & 0.562 & 0.393 & 2 \\
\hline 18 & 2 & 104 & 0.22 & 0.008 & 0.002 & 1 & 45 & 2 & 137 & 0.20 & 0.730 & 0.219 & 2 \\
\hline 19 & 3 & 61 & 0.49 & 0.937 & 0.447 & 1 & 46 & 4 & 58 & 0.73 & 0.270 & 0.163 & 3 \\
\hline 20 & 5 & 337 & 0.69 & 0.217 & 0.151 & 1 & 47 & 4 & 59 & 0.73 & 0.566 & 0.340 & 3 \\
\hline 21 & 2 & 97 & 0.22 & 0.199 & 0.005 & 1 & 48 & 4 & 95 & 0.65 & 0.284 & 0.171 & 3 \\
\hline 22 & 2 & 200 & 0.19 & 0.004 & 0.001 & 1 & 49 & 4 & 71 & 0.70 & 0.415 & 0.250 & 3 \\
\hline 23 & 2 & 9 & 0.45 & 0.503 & 0.151 & 1 & 50 & 2 & 27 & 0.30 & 0.764 & 0.230 & 3 \\
\hline 24 & 2 & 9 & 0.45 & 0.503 & 0.151 & 1 & 51 & 2 & 397 & 0.16 & 0.002 & 0.001 & 1 \\
\hline 25 & 5 & 268 & 0.71 & 0.616 & 0.430 & 2 & 52 & 3 & 641 & 0.30 & 0.002 & 0.001 & 3 \\
\hline 26 & 3 & 27 & 0.61 & 0.287 & 0.137 & 1 & 53 & 4 & 50 & 0.77 & 0.495 & 0.298 & 2 \\
\hline 27 & 1 & 20 & 0 & - & 0 & 2 & & & & & & & \\
\hline
\end{tabular}


Diversity, species richness, number of species and individual values were found in the similarity analysis through the formation of groups with 80 and $100 \%$ similarity (Fig. 2A, B). Sites with lower values of these indices $(1,10,11,12,27$; Table 2$)$ appear as a unit featuring $100 \%$ similarity, being places with high and intermediate coral coverage. The MDS (Fig. 2B) shows four main aggregations with a similarity of $80 \%$, particularly an aggregation of sites $(14,16,20,33,41,43$; Fig. 2A, B) that have high coral cover (Guzman et al. 2004, Guzman \& Breedy 2008) and additionally are the richest in species and have a high number of individuals. At the same time, there is another association between sites 4, 19, 32, 30, 35, 41, 42 and 44 (Fig. 2A, B), corresponding to sites with a range between 3 and 4 species and with a high number of individuals. However, according to the ANOSIM test there is no groups of sites significantly different to another $(\mathrm{R}=0.04, P=0.43)$. This is because the echinoids Diadema mexicanum and Eucidaris thouarsii had the highest similarity contribution (>90\%) in each group (Table 4), in other words, the most important species were in almost all the sites sampled. Whereas, the dissimilarity between groups is due to the presence of these two species associated to the echinoid Echinometra vanbrunti, the asteroids Pharia pyramidata and Phataria unifascilis and the holothuroid Isostichopus fuscus. No significant differences were observed between the total species ( $\mathrm{S}$; $\mathrm{H}=1.88, \mathrm{df}=2, P=0.39)$, total individuals $(\mathrm{N} ; \mathrm{H}=0.54$, $\mathrm{df}=2 ; P=0.76)$, Margalef species richness $\left(\mathrm{d} ; \mathrm{F}_{2,50}=\right.$ $1.22, P=0.33)$, Shannon diversity $\left(\mathrm{H}^{\prime} ; \mathrm{F}_{2,50}=0.726\right.$, $P=0.48)$, and Pielou's evenness $\left(\mathrm{J}^{\prime} ; \mathrm{F}_{2,50}=0.72, P=0.48\right)$ with respect to the coral cover level.

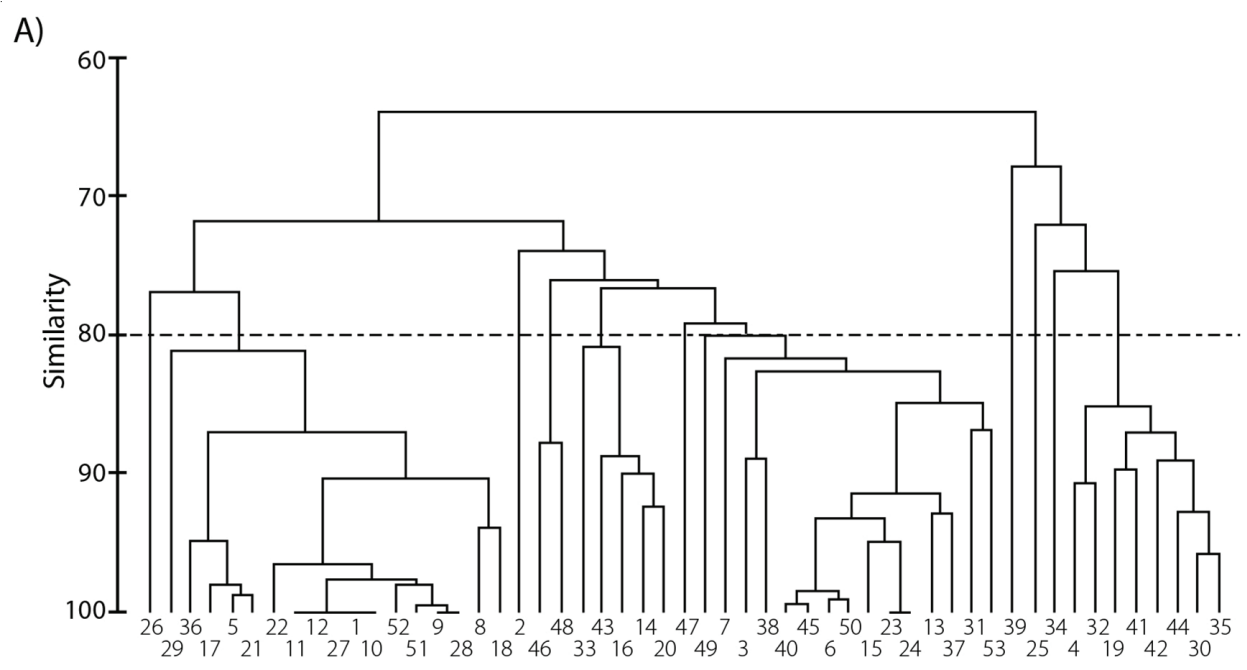

B)

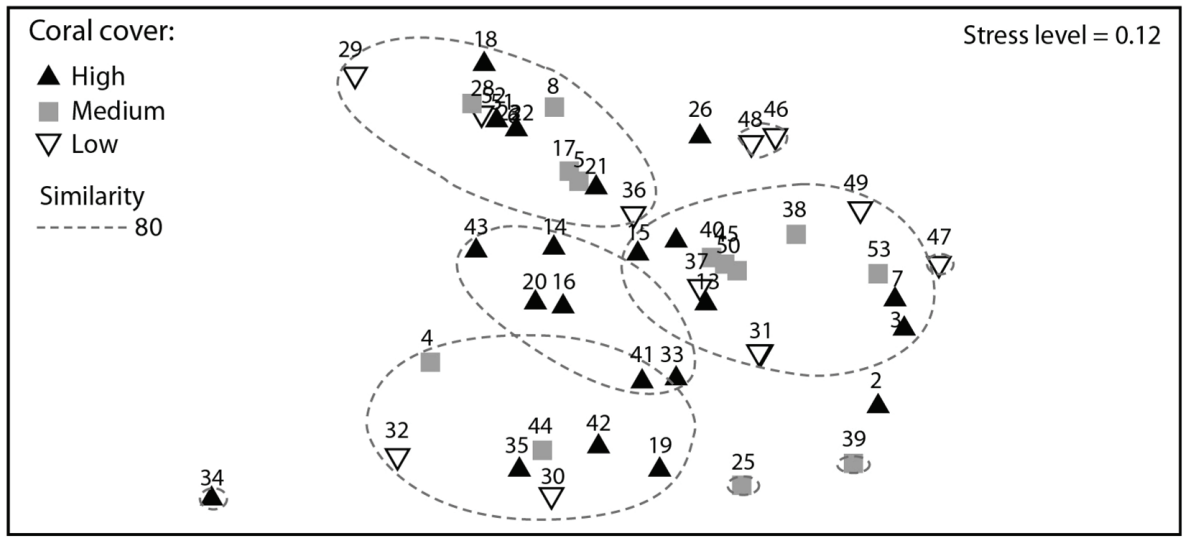

Figure 2. A) Cluster and B) multidimensional scaling (MDS) based on a Bray-Curtis similarity matrix using the total abundance of echinoderms per site in the Gulf of Chiriqui islands / A) Dendrograma y B) escalamiento multidimensional (MDS) basados en una matriz de similitud de Bray-Curtis utilizando la abundancia total de los equinodermos por sitio en las islas del Golfo de Chiriquí 
Table 4. Results from the Similarity Percentages (SIMPER) analysis that show the echinoderm species abundance contributions to groups by localities based on the level of coral cover / Resultados del análisis de similitud porcentual (SIMPER) que indica la abundancia de las especies de equinodermos que contribuyen a la agrupación de las localidades en base al nivel de cobertura de coral

\begin{tabular}{|c|c|c|c|c|c|}
\hline & \multicolumn{2}{|c|}{$\begin{array}{c}\text { Average } \\
\text { Abundance }\end{array}$} & $\begin{array}{l}\text { Average } \\
\text { similarity }\end{array}$ & $\begin{array}{c}\text { Contribution } \\
(\%)\end{array}$ & $\begin{array}{c}\text { Cumulative } \\
(\%)\end{array}$ \\
\hline High & & & 73.72 & & \\
\hline D. mexicanum & & & 60.40 & 81.93 & 81.93 \\
\hline E. thouarsii & & & 10.50 & 14.25 & 96.18 \\
\hline Medium & & & 73.86 & & \\
\hline D. mexicanum & & & 57.44 & 77.77 & 77.77 \\
\hline E. thouarsii & & & 15.02 & 20.33 & 98.10 \\
\hline Low & & & 70.54 & & \\
\hline D. mexicanum & & & 53.05 & 75.20 & 75.20 \\
\hline E. thouarsii & & & 16.08 & 22.79 & 97.99 \\
\hline High \& Medium & & & 25.9 & & \\
\hline E. thouarsii & 1.65 & 1.99 & 10.20 & 39.35 & 39.35 \\
\hline E. vanbrunti & 0.88 & 0.70 & 7.31 & 28.21 & 67.56 \\
\hline D. mexicanum & 4.37 & 4.41 & 1.78 & 6.88 & 74.44 \\
\hline High \& low & & & 27.77 & & \\
\hline E. thouarsii & 1.65 & 2.03 & 9.67 & 34.81 & 34.81 \\
\hline E. vanbrunti & 0.88 & 0.75 & 7.63 & 27.49 & 62.31 \\
\hline D. mexicanum & 4.37 & 4.36 & 1.93 & 6.95 & 69.26 \\
\hline P. unifascialis & 0.00 & 0.18 & 1.16 & 4.16 & 73.42 \\
\hline Medium \& Low & & & 26.64 & & \\
\hline E. thouarsii & 1.99 & 2.03 & 8.59 & 32.23 & 32.23 \\
\hline E. vanbrunti & 0.70 & 0.75 & 6.72 & 25.22 & 57.45 \\
\hline P. pyramidata & 0.16 & 0.14 & 1.53 & 5.74 & 63.19 \\
\hline I. fuscus & 0.18 & 0.13 & 1.50 & 5.63 & 68.82 \\
\hline D. mexicanum & 4.41 & 4.36 & 1.45 & 5.42 & 74.24 \\
\hline
\end{tabular}

\section{Discussion}

The effort to establish a regional methodology for assessing the status of invertebrate populations in the Marine Conservation Seascape of the Eastern Tropical Pacific (CMAR), promotes the understanding of processes such as coral recruitment and energy transfer (Carlon 2001, Carreiro-Silva \& McClanahan 2001, McClanahan 2002), as well as erosion processes (Scoffin et al. 1980, Eakin 2001). This kind of information is vital in establishing conservation strategies within and outside protected areas (e.g., core zoning, use restrictions, closures, quotas) and to understand regional connectivity processes among populations (Edgar et al. 2004, 2007). In comparative terms, the islands of the Gulf of Chiriqui have a species composition very similar to that observed in all the islands of the CMAR (Edgar et al. 2004, Alvarado \& Chiriboga 2008, Cohen-Rengifo 2008), as well as the
Marino Ballena National Park (Alvarado \& Fernández 2005) and Caño Island Biological Reserve (J.J. Alvarado, pers. obs.), located in the southern Pacific, Costa Rica, geographically close to the Gulf of Chiriqui. In all the islands of the Gulf, there were 17 species of echinoderms, a similar number as observed in Mapelo (13 species; Cohen-Renfigo 2008), Marino Ballena (18 species; Alvarado \& Fernández 2005), Cocos Island (11 species, Alvarado \& Chiriboga 2008) and Galapagos (23 species; Edgar et al. 2004). This indicates that the methodology is consistent in locating and describing species of large, mobile, and conspicuous echinoderms, but leaving out those cryptic or smaller, so it is possible that species richness in these places is greater than that presented in this study, as well as in other studies. 
In general, the composition, distribution, abundance, and diversity of shallow water echinoderms is very similar along the studied islands and islets (Table 3, Fig. 2) in the Gulf of Chiriqui. Most of the species were present in low densities $\left(<0.04\right.$ ind $\left.\mathrm{m}^{-2}\right)$, a factor that affects the diversity indices. Only 3 species of sea urchins showed high numbers of abundance and density (Table 2): Diadema mexicanum (7909 individuals, 0.77 ind. $\mathrm{m}^{-2}$ ), Eucidaris thourasii (771 individuals, 0.11 ind. $\mathrm{m}^{-2}$ ) and Echinometra vanbrunti (569 individuals, 0.25 ind. $\mathrm{m}^{-2}$ ). These species were present in the majority of studied sites, while the other 14 species were in lower numbers and in fewer sites, reason why the ANOSIM indicates that there is not a difference among the groups in the MDS (Fig. 2). Moreover, these 3 sea urchins explain in greater measure the similarity and dissimilarity between the study sites, due to the fact that they are the most abundant.

In most of these locations, the predominant species of sea urchins is Diadema mexicanum. In the Gulf of Chiriqui, the average density was $0.77 \pm 0.12$ ind. $\mathrm{m}^{-2}$, with a minimum of 0.01 and a maximum of 9.05 ind. $\mathrm{m}^{-2}$ (Table 2), while in Cocos Island, Alvarado and Chiriboga (2008) reported densities ranging between 0.05 and 6.53 ind. $\mathrm{m}^{-2}$. In Malpelo, Cohen-Renfigo (2008) indicates densities between 2.98 and 3.09 ind $\mathrm{m}^{-2}$, while in the Galapagos the lowest densities are reported ranging between 0.001-0.654 ind. $\mathrm{m}^{-2}$. This indicates that Coiba presents the highest densities of this sea urchin along the CMAR.

Historically, this sea urchin, Diadema mexicanum, has had a detrimental impact on the coral reef of Uva Island (site 16), in Contreras (Fig. 1). Between 1978 and 1983 the densities of this sea urchin were between 2 and 4 ind. $\mathrm{m}^{-2}$ at the reef-base (Glynn 1990). After that, the El Niño event occurred (1982-1983) and this sea urchin's populations increased, so the density fluctuated between 60 and 90 ind. $\mathrm{m}^{-2}$ between 1985 and 1989 (Glynn 1990). Glynn (1988) and Eakin $(1992,1996,2001)$ quantified the impact of bioerosion from 1974 to 2000, which increased from 10 to $20 \mathrm{~kg} \mathrm{CaCO} 3 \mathrm{~m}^{-2} \mathrm{yr}^{-1}$, exceeding the net

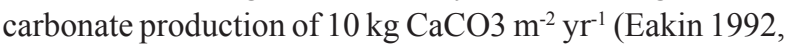
2001). The current average densities on islands in the Gulf of Chiriqui are below those reported by Glynn (1990), prior to the El Niño (1982-1983), indicating a decrease in the potential bioerosive impact that they might be causing Uva Island as well as the rest of the islands in the gulf. However, all this applies only to at Uva Island and does not necessarily explain the process in other locations of Panama and the Eastern Pacific. Also, in view that site 9 had the highest densities ( 9.05 ind $\mathrm{m}^{-2}$ ), it is possible that during the after-effects of the El Niño, the site was under a major setback in the bioacretion of the coral framework as observed in Uva Island. However, these densities are not a threat to the reefs of Coiba where trophic cascades are settling and the diversity and biomass of fish has increased significantly (unpublished results). Similarly, trophic cascades have not been recovered outside the protected area, showing a fish biomass three times lower than within the protected area (unpublished results). The cascade effect caused by the ban on fishing in marine reserves, highlights the potential role of small predatory fish to control sea urchin populations (Hereu et al. 2005), being lower under their presence (McClanahan \& Sala 1997). Marine protected areas represent an effective way to protect biodiversity, reef structure and processes when banning fishing and preventing the proliferation of sea urchins (Carreiro-Silva \& McClanahan 2001).

Another organism that has an important role in the reefs of the ETP, is the crown-of-thorns seastar, Acanthaster planci. The population of this seastar, in the Uva reef, has remained stable from around 1970 to 1980, with densities between 7 and 30 ind. ha ${ }^{-1}$, being comparable with the Indo-Pacific sites where this seastar is not considered a threat (Glynn 1974, 1981). Contrary to the case of Diadema, this species did not experience any increase (or did not experience any increase?) any increase in density after the El Niño event, despite the availability of food, keeping their populations at very similar numbers to previous years (Glynn 1990). In the present research, Acanthaster only appeared in 3 of the 53 sites sampled, indicating low densities within the gulf, not representing a threat to the reefs in the region.

Although the majority of sampling sites are inside a vast protected area (Guzman et al. 2004), a major threat to marine resources in the area is the illegal fishing and harvesting of organisms for aquariums (Guzman \& Breedy 2008). The sea cucumber Isostichopus fuscus, has been one of the most over-fished species in the ETP and is extracted illegally in Panama, although by law this activity is prohibited (ToralGranda 2008). Populations observed in this study are low, and very similar to those observed elsewhere within the ETP (Edgar et al. 2004, Alvarado \& Chiriboga 2008, CohenRengifo 2008), which strongly questions whether conservation and management strategies are really working against the illegal extraction of this species.

It is important to note that the most diverse and dense sites with echinoderms are found in the Coiba National Park. The places with the poorest diversity were dominated by $D$. mexicanum, and these were associated 
with sites exhibiting high coral cover but low coral species diversity. Sites with a greater richness and echinoderm species diversity were associated with sites of the greatest diversity of coral species and coral coverage ranging from moderate to high, according to research conducted by Guzman et al. (2004) and Guzman \& Breedy (2008), mostly within the CNP. Hence, it is necessary to focus on conservation, monitoring and management strategies in places where there is a synergy between richness, coral cover and diversity of echinoderms, in order to maintain these patterns of richness and diversity, while monitoring any increase in the populations that may affect these ecosystems.

\section{ACKNOWLedgments}

This study would not have been possible without the help of the crew of the R/V Urracá. We want to thank C. Guevara, A. Chiriboga, G. Edgar and J. Cortes for their help with field work. We give special thanks to J. Cortés and two anonymous reviewers for all the comments that enriched this manuscript. This study was partially funded by Conservation International and the Smithsonian Tropical Research Institute. JJA is grateful with the Ministerio de Ciencia y Tecnología de Costa Rica (MICIT), Consejo Nacional para Investigaciones Cientí-ficas y Tecnológicas de Costa Rica (CONICIT) and Consejo Nacional de Ciencia y Tecnología de México (CONACYT).

\section{LITERATURE CITED}

Alvarado JJ \& A Chiriboga. 2008. Distribución y abundancia de equinodermos en las aguas someras de la Isla del Coco, Costa Rica (Pacífico Oriental). Revista de Biología Tropical 56 (Supl. 2): 99-111.

Alvarado JJ \& C Fernández. 2005. Equinodermos del Parque Nacional Marino Ballena, Pacífico, Costa Rica. Revista de Biología Tropical 53(Supl. 3): 275-284.

Alvarado JJ, FA Solís-Marín \& C Ahearn. 2010. Echinoderms (Echinodermata) diversity off Central America Pacific. Marine Biodiversity 40(1): 45-56.

Bellwood DR, TP Hughes, C Folke \& M Nyström. 2004. Confronting the coral reef crisis. Nature 429 (6994): 827833.

Birkeland C. 1989. The influence of echinoderms on coralreef communities. In: Jangoux M \& JM Lawrence (eds). Echinoderm Studies 3: 1-79. A.A. Balkema, Rotterdam.

Carlon DB. 2001. Depth-related patterns coral recruitment and cryptic suspension-feeding invertebrates on Guana Island, British Virgin Islands. Bulletin of Marine Science 68(3): 525-541.
Carreiro-Silva M \& TR McClanahan. 2001. Echinoid bioerosion and hervibory on Kenyan coral reefs: the role of protection from fishing. Journal of Experimental Marine Biology and Ecology 262(2): 133-153.

Clarke KR \& RN Gorley. 2005. PRIMER v6: user manual, 190 pp. PRIMER-E, Plymouth.

Cohen-Rengifo M. 2008. Equinodermos del Santuario de Fauna y Flora Malpelo, Pacífico Colombiano. Tesis Licenciatura en Biología, Universidad Jorge Tadeo Lozano, Bogotá, 117 pp.

Cortés J. 2007. Coastal morphology and coral reefs. In: Bundschuh J \& G Alvarado (eds). Central America: Geology, resources and hazards 1: 185-200. Taylor \& Francis, London.

D'Croz L \& DR Robertson. 1997. Coastal oceanographic conditions affecting coral reefs on both sidesof the Isthmus of Panama. Proceedings of the $8^{\text {th }}$ International Coral Reef Symposium, Panama 2: 2053-2058.

D'Croz L \& A Odea. 2007. Variability in upwelling along the Pacific shelf of Panama and implications for the distribution of nutrients and chlorophyll. Estuarine and Coastal Shelf Science 73(1-2): 325-340.

Dexter D. 1977. A natural history of the sand dollar Encope stokesi L. Agassiz in Panama. Bulletin of Marine Science 27(3): 544-551.

Eakin CM. 1987. Damselfishes and their algal lawns: a case of plural mutualism. Symbiosis 4(1-3): 275-288.

Eakin CM. 1992. Post-El Niño Panamanian reefs: less accretion, more erosion and damselfish protection. Proceeding of the $7^{\text {th }}$ International Coral Reef Symposium, Guam 1: 387-396.

Eakin CM. 1996. Where have all the carbonates gone? A model comparison of calcium carbonate budgets before and after the 1982-1983 El Niño at Uva Island in the Eastern Pacific. Coral Reefs 15(2): 109-119.

Eakin CM. 2001. A tale of two ENSO events: carbonate budgets and the influence of two warming disturbances and intervening variability, Uva Island, Panama. Bulletin of Marine Science 69(1): 171-186.

Edgar GJ, S Banks, JM Fariña, M Calvopiña \& C Martínez. 2004. Regional biogeography of shallow reef fish and macro-invertebrate communities in the Galápagos archipelago. Journal of Biogeography 31(7): 1107-1124.

Edgar GJ, GR Russ \& RC Babcock. 2007. Marine protected areas. In: Connell SD \& BM Gillanders (eds). Marine ecology, pp. 533-555. Oxford University, Melbourne.

EGUP. 2001. Diccionario geográfico de Panamá. Vol. I y II, 115 pp. Ed. Universitaria, Ciudad de Panamá.

Fong P \& PW Glynn. 1998. A dynamic size-structured population model: does disturbance control size structure of a population of the massive coral Gardineroseris planulata in the Eastern Pacific? Marine Biology 130(4): 663-674. 
Glynn PW. 1973. Acanthaster: Effect on Coral Reef Growth in Panama. Science 180(4085): 504-506.

Glynn PW. 1974. The impact of Acanthaster on corals and coral reefs in the eastern Pacific. Environmental Conservation 1(4): 295-304.

Glynn PW. 1977. Interaccions between Acanthaster and Himenoceras in the field and laboratory. Proceedings of the $3^{\text {th }}$ International Coral Reef Symposium, Miami 1: 209-215.

Glynn PW. 1981. Acanthaster population regulation by a shrimp and a worm. Proceedings of the $5^{\text {th }}$ International Coral Reef Symposium, Manila 2: 607-612.

Glynn PW. 1982. Individual recognition and phenotypic variability in Acanthaster planci (Echinodermata: Asteroidea). Coral Reefs 1(2): 89-94.

Glynn PW. 1984. An amphinomid worm predator of the crownof-thorns sea star and general predation on asteroids in Eastern and Western Pacific corals. Bulletin of Marine Science 35(1): 54-71.

Glynn PW. 1985a. Corallivore population size and feeding effects following El Niño (1982-83) associated coral mortality in Panama. Proceedings of the $5^{\text {th }}$ International Coral Reef Symposium, Tahiti 4: 183-188.

Glynn PW. 1985b. El Niño associated disturbance to coral reefs and post disturbance mortality by Acanthaster planci. Marine Ecology Progress Series 26(3): 295-300.

Glynn PW. 1988. El Niño warming, coral mortality and reef framework destruction by echinoid bioerosion in the eastern Pacific. Galaxea 7(2): 129-160.

Glynn PW. 1990. Coral mortality and disturbances to coral reef in the Tropical Eastern Pacific. In: Glynn PW (ed). Global ecological consequences of the 1982-83 El NiñoSouthern Oscillation, pp. 55-126. Elsevier, Amsterdam.

Glynn PW \& JS Ault. 2000. A biogeographic analysis and review of the far eastern Pacific coral reef region. Coral Reefs 19(1): 1-23.

Guzman HM \& O Breedy. 2008. Distribución de la diversidad y estado de conservación de los arrecifes coralinos y comunidades coralinas del Pacífico occidental de Panamá (Punta Mala-Punta Burica), 40 pp. The Nature Conservancy, Arlington.

Guzman HM, CA Guevara \& O Breedy. 2004. Distribution, diversity, and conservation of coral reefs and coral communities in the largest marine protected area of Pacific Panama (Coiba Island). Environmental Conservation 31(2): 111-121.

Guzman HM, S Benfield, O Breedy \& JM Mair. 2008. Broadening reef protection across the Marine Conservation Corridor of the Eastern Tropical Pacific: distribution and diversity of reefs in Las Perlas Archipelago, Panama. Environmental Conservation 35(1): 46-54.

Hendler G, MJ Grygier, E Maldonado \& J Denton. 1999. Babysitting brittle stars: heterospecific symbiosis between ophiuroids (Echinodermata). Invertebrate Biology 118(2): 190-201.
Hereu B, M Zabala, C Linares \& E Sala. 2005. The effects of predator abundance and habitat structural complexity on survival of juvenile sea urchins. Marine Biology 146(2): 293-299.

Hughes TP. 1994. Catastrophes, phase shifts and large-scale degradation of a Caribbean coral reef. Science 265(5178): 1547-1551.

Lessios HA. 1979. Use of Panamanian sea urchins to test the molecular clock. Nature 280(5723): 599-601.

Lessios HA. 1981. Divergence in allopatry: molecular and morphological differentiation between sea urchins separated by the Isthmus of Panama. Evolution 35(4): 618-634.

Lessios HA. 1990. Adaptation and phylogeny as determinants of egg size in echinoderms from the two sides of the Isthmus of Panama. American Naturalist 135(1): 1-13.

Lessios HA. 2005. Echinoids of the Pacific waters of Panama: status of knowledge and new records. Revista de Biología Tropical 53(Supl. 3): 147-170.

Lessios HA. 2010. Speciation in sea urchins. In: Harris LG, SA Bottger, CW Walker \& MP Lesser (eds). Proceedings of the $12^{\text {th }}$ Echinoderm Conference, Durham, New Hampshire, pp. 91-101. CRC Press, London.

Lessios HA, BD Kessing \& JS Pearse. 2001. Population structure and speciation in tropical seas: global phylogeography of the sea urchin Diadema. Evolution 55(5): 955-975.

McClanahan TR. 2002. A comparison of the ecology of shallow subtidal gastropods between western Indian Ocean and Caribbean coral reefs. Coral Reefs 21(4): 399-406.

McClanahan TR \& E Sala. 1997. A Mediterranean rockybottom ecosystem fisheries model. Ecological Modelling 104(2-3): 145-164.

Maluf YV. 1988. Biogeography of the central eastern Pacific shelf echinoderms. In: Burke RD, PV Madlenov, P Lambert \& RL Parsley (eds). Echinoderm biology, pp. 389-398. Balkema, Rotterdam.

Maté JL. 2003. Corals and coral reefs of the Pacific coast of Panama. In: Cortés J (ed). Latin American Coral Reefs, pp. 387-417. Elsevier, Amsterdam.

Scoffin TP, CW Stearn, D Boucher, P Frydl, CM Hawkins, JG Hunter \& JK MacGeachy. 1980. Calcium carbonate budget of fringing reef of the West coast of Barbados. Part II. Erosion, sediments and internal structure. Bulletin of Marine Science 30(2): 475-508.

SYSTAT. 1998. SYSTAT for Windows. Version 8 edition, 676 pp. Evanston, Illinois.

Toral-Granda V. 2008. Population status, fisheries and trade of sea cucumbers in Latin America and the Caribbean. In: Toral-Granda V, A Lovatelli \& M Vasconcellos (eds). Sea cucumbers. A Global Review of Fisheries and Trade. FAO Fisheries and Aquaculture Technical Paper 516: 213-229.

Received 6 July 2011 and accepted 6 December 2011 